\title{
Manduda Dance in Simalungun Community Dancing Style in a Contextual Perspective
}

\author{
Ruth Hertami Dyah Nugrahaningsih \\ Dance Education Study Program, Faculty of Languages and Arts, Universitas Negeri Medan, Indonesia \\ hertamiruth@yahoo.com
}

\section{Abstract}

This study aims to explain: 1) the relationship of body attitude in Manduda Dance with the activities of the Simalungun community; 2) the relationship between the type of transition in Manduda dance and the activities of Simalungun community; 3) the relationship between the number of active body part in Manduda dance and the patterns of daily activities of Simalungun community; 4) the relationship between business forms and the patterns of study is the formulation of dance style in Manduda dance on Simalungun community in a contextual perspective. The research method used is a qualitative-anthropological approach, specifically called choreometrics, which is to analyze the relationship between dance movements including body attitude, type of transition, the number of active body part, and the forms of business with patterns of daily community activities. Observation, documentation, and interview techniques were used to collect data and then the triangulation data analysis process was carried out to obtain the credibility of the data. The results of this study found that both viewed from body attitude, type of transition, the number of active body part, as well as the forms of effort contained in Manduda dance, were very closely related to the patterns of daily activities of Simalungun community patterned with paddy harvesting agricultural activities.
Keywords

Manduda dance; dance style; contextual perspective

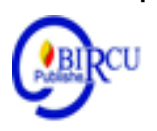

\section{Introduction}

Manduda dance is a dance that tells about the activities of Simalungun daughters pounding paddy together in excitement because of a successful harvest. In its function as an entertainment dance, Manduda dance that appears on various occasions needs to be welcomed with pride, because it helps maintain the survival of the art (dance) Simalungun. The development of the use of this dance led to the emergence of various forms and styles of presentation, making it difficult to determine which standard Manduda dance.

Manduda dance is a dance creation that is inherited, because it is often shown and then becomes a marker and symbol of identity for Simalungun tribe. In general, the majority of Simalungun community is farmers. In addition to planting paddy as the main crop, the Simalungun community also grows corn, because paddy is a daily staple food and corn is an additional food if paddy is not sufficient. Life as farmers makes them familiar with the pattern of living together so they live in a strong sense of family ties. The mutual cooperation system is run based on consensus agreement

Farming activities generally begin with cleaning the fields, blowing up the soil, sowing the seeds, caring for the plants, and harvesting the results. The joy of an abundant harvest is expressed in various ways, one of which is by dancing known as Manduda Dance. This dance illustrates the happiness of a successful paddy harvest. Tells the joy when pounding paddy, 
winnowing paddy, until it becomes rice which is done together, as a reflection of mutual cooperation in the community.

The presence of dance in Simalungun community is closely related to its cultural image. This fact is in line with the opinion of Sedyawati (1986: 3) who said that "dance is a statement or reflection of the culture of the supporting community. As a reflection or cultural expression, dance communicates the conditions that exist and are owned by the supporting community. "Dance as a nonverbal language is able to provide the identity adopted by its supporters through the style they have. Therefore, the types of dance styles become very diverse. Each ethnic group has several styles and sub-dance styles, such as Javanese, having Surakarta dance style and Yogyakarta dance style. Surakarta dance style in female dancer category also has two appearance styles namely Bedaya and Gambyong. Sedyawati (1999: 14), confirmed this condition by giving examples of dance in Minangkabau which has various types of dance, which are spread in various villages.

\section{Review of Literature}

Dance style can be seen from the textual and contextual side. Sedyawati (1986: 12-13) states that textual dance style is related to what is called a technique, determines the characteristics of a dance style, and provides a visual experience that is artistic for the audience, as well as the beauty of motion seen from the rhythm of the motion. While the contextual dance style is an inner attitude that is felt as something appropriate, according to the cultural values framework in question. In other words, the inner attitude is an aspect of living up to cultural values. Therefore, the peculiarity of dance style is not only influenced by its geographical location but also by the cultural system, patterns of daily activities, as well as the orientation of the cultural values of the supporting communities.

Manduda dance is one of the dances that reflects the existence of Simalungun community, which will be examined in a contextual dance style. This research is expected to be useful in reinforcing cultural understanding through the expression and reflection of Manduda dance in Simalungun, with the main focus being: how is the relationship between the movement style of Manduda dance and the patterns of Simalungun community activities.

In art, style according to Allee in Royce (1977: 170) can mean the tendency of acting, expression, and performance that is typical of a group. In dance, Sedyawati (1981: 187) explains that style is commonly understood as a group of characteristics of a dance tradition or a particular dance habit, which distinguishes it from other dance traditions or customs. According to Lomax (1978: 236), the relationship between dance movements and everyday life is called Choreometrics. Lomax describes and compares dance styles and culture according to the type of movement, cultural region, and cultural area, as found in daily life (work) and expression activities (dance).

The theory of dance movement style by Alan Lomax concluded that, the movement style in dance is the crystallization of the patterns of daily activities that are very frequent and important in the supporting community. Lomax argues that there are four factors that shape dance style as a crystallization of the pattern of daily activities that are very prominent and important in the supporting community, namely: 1) body attitudes; 2) type of transition; 3) number of active body part; and 4) effort-shape. 


\section{Research Method}

The specific target of this research was the formulation of dance style in Manduda dance in Simalungun community in a contextual perspective. The research method used was a qualitative-anthropological approach, specifically called choreometrics, which was to analyze the relationship between dance movements including body attitude, type of transition, the number of active body part, and the forms of business with patterns of daily community activities. Observation, documentation, and interview techniques were used to collect data and then the triangulation data analysis process was carried out to obtain the credibility of the data.

\section{Discussion}

The majority of Simalungun community make a living as farmers. Aside from planting paddy as the main crop and also grows the corn. Paddy is a daily staple food, while corn is used as additional food if paddy is insufficient. Life as farmers makes them familiar with the pattern of living together so they live in a strong sense of family ties. The mutual cooperation system is run based on consensus agreement. The mutual cooperation motto in Simalungun is pronounced as follows:

1. Marsialop ari = alop arimu hu jumangku, hualop aringku hu jumamu, every ma hita marhorja margantih-gantih bani jumanta bei (take your day to my field, I take my day to your field, let's work alternately in each field).

2. Marharoan = ra ham my jumu spirit, ra ahu hujon spirit. Every maragurupan ibagas riah na madear (you love coming to my fields, I love coming to your fields, I help you and you help me).

In the past, Simalungun community did not have permanent agricultural land. They use the forest to be used as agricultural land. That is why the agricultural land of Simalungun community always moves, from one forest to another forest. The farming system with shifting land is in accordance with the wishes of Simalungun community in the past, which is reforesting the land that has been used so that the land remains fertile.

\subsection{The origin of Manduda Dance}

Manduda dance originated from an ilah that developed into a doding that was given the title doding Manduda. This doding consists of 2 pieces of doding namely doding Manduda and doding Sermadengan-dengan which be one, becoming accompaniment doding on Manduda dance, so it is entitled doding Manduda. Ilah and doding in Indonesian is interpreted as 'singing'. But for Simalungun community, doding is understood as a song that is sung solo (one person), while ilah is a song that is sung together (many people). At present, if adapted into the Simalungun traditional musical instrument, there is no longer any difference between the Ilah and doding.

Doding or Ilah is a song that contains a message that young people respect older people, but it also illustrates the togetherness in doing various jobs. The message aims to make young people respectful and responsible for their work. As shown in Manduda dance, which shows togetherness in working on the harvest. In the harvesting activity, many processes or stages are carried out, including the activities of aerating paddy to separate straw and grain, pounding grain, taking the results that have been crushed and then being displayed to be separated to separate paddy husks and rice, then upheld to be moved to the rice storage. That process is then poured into Manduda dance movement. 
Doding Manduda became an inspiration for a Simalungun artist named Taralamsyah Saragih to create a dance called Manduda which means pounding paddy. Taralamsyah uses a slow tempo in doding Manduda to make the process of pounding paddy until winnowing paddy and doing joyful movements in accordance with the tempo in doding Sermadengan-dengan. Manduda dance is a folk dance so that it runs as a result of bringing the style of the community itself.

\subsection{Manduda Dance Motion Techniques}

The basic technique of movement in Manduda dance is in line with the rules found in the community. There are four basic movements that are dominant in dance Simalungun, namely ondok, herbang, manerser and eot. Ondok is a movement done on both legs. The basic technique of ondok movement illustrates the power in the lives of Simalungun community. Herbang is a swinging wrist movement. Basically the movement of herbang only moves the wrist but the movement of the herbang can also be developed in accordance with the motion of the dance. Herbang motion techniques mean that humans are social creatures who need each other well in difficult and happy situations. Manerser is a leg movement that is done by sliding both legs open and closed by forming a triangle pattern towards the right or left. The manerser motion technique shows harmony in Simalungun community. Eot is a downward movement with your right foot flat on the floor while your left foot is slightly backward and slightly tiptoes. Eot motion technique shows the balance that occurs both in performing dance moves and in the life of Simalungun community.

\subsection{Variety of Motion}

In the Manduda dance, there are 15 movements with the details of 10 movements using doding Manduda as accompaniment music, and 5 movements using doding Sermadengandengan as accompaniment music. The names of the various motions are as follows:

a. With doding Manduda as accompanist: 1) Mamboban omei hulosung, 2) Manduda omei, 3) Mangahut boras, 4) Mangeot hutoruh, 5) Herbang hampit siamun (kanan) dan hampit siambilo (kiri), 6) Mamiari boras, 7) Memilih omei ni boras, 8) Mangeot huatas, 9) Manerser mamiari boras, 10) Mamboban boras hu lopah or Mengangin-anginkan omei.

b. With doding Sermadengan-dengan as accompaniment: 1) Manortor girang-girang, 2) Manerser manortor riap, 3) Marhusip-husip pakon hasoman sambil marsitandaan, 4) Mangarahkon hasoman laho manortor girang, and 5) Riap mulak hu lanan ni.

\subsection{Style and Pattern of Activity}

From the data collected, it can be described that Manduda dance is a new dance of creation that became a traditional dance in Simalungun ethnic. Drawn by a group of female dancers with an irregular amount, generally even. The dancer's waist is tied to a dagger or scarf which is then used as a dance property, the personification of the place where the paddy is won. The duration of the show ranges from five to six minutes. Dance movement is divided into two parts, namely the part that describes the activities of farmers pounding paddy into rice, and the joy of the success of the harvest. The whole range of movements is the daily movements of farmers which contain activities of farmers after finishing picking paddy and still patterned on Simalungun dance movement techniques.

Manduda dance is composed of two major parts according to the accompanying doding, containing fifteen (15) variations of movements, presenting a unity of dance forms that illustrate the patterns of activities of Simalungun community who initially made their living as 
farmers. The overall range of motion has specific motion characteristics, which are in harmony with the Simalungun dance technique, so that it is different from other ethnic dance movements. The range of motion raised from the activity of processing paddy to rice is the range of motion:

1. Mamboban omei hulosung (bringing paddy to the ground)

2. Manduda omei (pounding paddy), the body that bends up and down

3. Mangahut boras (taking paddy from pounding),

4. Mangeot hutoruh (down),

5. Herbang almost siamun (right) and almost siambilo (left) (swinging hands on right and left side),

6. Mamiari boras (winnowing paddy),

7. Memilih omei ni boras (separating paddy from rice),

8. Mangeot huatas (up),

9. Manerser mamiari boras (moves sideways while winnowing rice)

10. Mamboban boras hu lopah or Aerate omei (aerate rice to separate rice grain from paddy).

While the range of motion that describes the happiness of Simalungun girls after completing their activities or work are:

1. Manortor girang-girang (dancing together interspersed with clapping)

2. Manerser maniapor riap (dancing together while moving to confirms a sense of joy),

3. Marhusip-husip pakon hasoman sambil marsitandaan (whispering fellow the youngest)

4. Mangarahkon hasoman laho manortor girang (invite friends to dance together), and

5. Riap mulak hu lanan ni (return to each other's house while still rejoicing)

The above movement style in Manduda dance, is a crystallization of the patterns of daily activities that are very frequent and important in Simalungun community. The range of motion is analyzed using the perspective of theoretical study as stated earlier.

\subsection{Body Attitudes}

By knowing the body attitude that is most often used in Manduda dance, it can be observed the life activity patterns of Simalungun community. Through body attitude can be explained the basic patterns of supporting culture. Whatever activities they do, will be seen in the basic pattern and visible from their body attitude which has crystallized in their daily activities.

Manduda dance as a reflection of people's behavior, also displays the body attitude that they have had, lived and accustomed to. By observing the dominant body attitude in this dance, they will know and understand their dominant daily work. Through this research, an understanding that a permanent or consistent body attitude arises from each range of motion is always showing the position of the body close to the ground, dancers lowering their bodies to their knees and at the same time leaning forward. This can be seen clearly in the range of motion Mangeot hutoruh, Herbang hampit siamun and hampit siambilo, Mamiari boras, Memilih omei ni boras, Mamboban boras hu lopah or Mengangin-anginkan omei.

If the description of body attitude above is related to the patterns of activities of Simalungun community whose main work is farmers, it can be seen that the body attitude shown in Manduda dance is very commensurate with the work they do in the fields. The body attitude shown is the crystallization of their activity patterns. In addition, in line with the existing body attitude with the pattern of activities, the name of the range of motion is dominant using mock movements from the community carrying out post-harvest activities. 


\subsection{Transition Type (Type of Transition)}

Manduda dance has several types of transitions, but the dominant types of transitions are: 1. A jogging transition

2. Manerser transition

3. A simple spin and a full spin transition

4. Transition exposes the body to the right and left, while turning right and left wrists,

All of the above transitions are included in complex transitions. Transitions that are less complicated than the above transitions are: a simple turning transition forward accompanied by a transition to two hands from the head to the side of the thigh-high body and vice versa. Furthermore, a simple transition is seen on the two legs that go up and down and walk home, seen on the range of motion increment mulak hu lanan ni. More clearly, the type of transition in Manduda dance can be seen in the following table:

Table 1. Types of Transitions in Manduda Dance

\begin{tabular}{|c|l|l|l|}
\hline No & Complicated Transition & Less Complex Transition & Simple Transition \\
\hline 1 & Jogging transition & $\begin{array}{l}\text { A simple forward turn } \\
\text { transition is accompanied } \\
\text { by a transition of both } \\
\text { hands from the head to } \\
\text { the side of the body at } \\
\text { the level of the thigh }\end{array}$ & $\begin{array}{l}\text { Seen on both legs } \\
\text { up and down and } \\
\text { walk home }\end{array}$ \\
\hline 3 & Manerser transition & $\begin{array}{l}\text { A simple and full spin } \\
\text { transition }\end{array}$ & $\begin{array}{l}\text { The transition exposes the } \\
\text { body to the right and left, } \\
\text { while rotating the right and } \\
\text { left wrists }\end{array}$
\end{tabular}

In line with the types of transitions in the Manduda dance above, this dance is a crystallization of the activity patterns of Simalungun community as an agricultural society that grows crops.

\subsection{The Number of Active Body Parts}

The number of active body parts is a reflection of the daily life of the supporting community. Thus, The number of active body parts in Manduda dance emphasize that in daily life, they also often use these body parts. The use of body parts in dancing is used as an expressive instrument. In general, the use of the body as an expressive instrument is divided into four parts, namely: head, body, hands and feet. The four parts of the body can still be broken down into their respective sub-parts, such as the hand consisting of the upper arm, forearm, hand and fingers. The foot consists of upper limbs, lower limbs and feet.

In Manduda dance, hand involvement is seen in all movements, both in the various movements with doding Manduda as accompanist, and the range of movements with doding Sermadengan-dengan as accompanist. The relatively special hand movements are seen in the range of motion that holds the suri-suri (manerser mamiari boras), where there is a swinging of the wrist along with the rhythm of the accompaniment. Foot involvement is seen in all variations of motion except in the various kneeling movements called mamiari boras, memilih omei ni boras, and mengangin-anginkan omei. There are also bodies that lean forward, such as Manduda omei, Mangahut boras hanlosung, and Mangahut boras hanlosung. The involvement of the head is almost not found, because the view is always facing straight ahead. In spontaneous connecting movements, dancers look more downward. 
Based on data collection on the involvement of the hands, feet, body and head above, it can be found active body parts in Manduda dance sequentially, namely: the most active are the hands and are followed by the movements of the legs, head and body parts. Then the movement with the most variations is also found in the involvement of the hand.

The meaning of the most active and varied hand involvement in Manduda dance is that Simalungun community in their dance moves are in line with their habit of moving their crops, from rice to rice always involving the hand as the center of motion in their activities. While the use of legs is as a supporting element of dance movements, especially in manduda omei movements to emphasize the intention of pounding paddy.

Based on the explanation above, it can be concluded that Manduda dance style seen from the number of active body members, is largely determined by the pattern of agricultural activities that have been their main life in Simalungun.

\subsection{Effort and Shape}

The shape in this study is how the motion carried out by a dancer in accordance with the surrounding space, while the business is related to how the energy of motion is adjusted according to its proportions to produce rhythmic quality in motion. To measure dance as a cultural measure is to analyze the quality of dynamics through its business forms. Explanations for assessing business elements are done by looking at the number of elements involved, and the types of combinations. Then, the way to relate it to community activities is to look at one of its dominant businesses, meaning that the business reflects precisely the community's activities.

In Manduda dance, the movements that make up space are visible from direct motion, indirect motion, and combination motion. The movements carried out immediately can be seen in the various movements of manduda omei, mangahut boras hanlosung, and boras mamiari. Indirect motion can be seen in the range of motion of mamboban omei hulosung, memilih omei ni boras, mamboban boras hu lopah, and mengangin-anginkan omei. While the combination of motion is seen in the range of the movements of the manerser mamiari boras, mangeot hutoruh, herbang hampit siamun and hampit siambilo (left).

In the energy element, the explanation is divided into two categories: strong and light. Strong power can be seen in the movement of manduda omei, manerser mamiari boras, memilih omei ni boras, mamboban boras hu lopah, and mamiari boras. While the light energy element can be seen in the various movements of the manortor girang-girang, and manerser manortor riap. There are also two kinds of time elements, namely the medium tempo in doding Manduda which accompanies ten (10) motions, and the faster tempo in doding Sermadengandengan, with the accompanying five (5) motions.

\section{Conclusion}

Based on the results of the study it can be concluded that Simalungun community who are farmers, are familiar with their work as farmers when harvesting paddy and pounding it into rice. This is reflected in the dancers' leaning and close attitude to the ground. The complicated type of Manduda dance transition is a habit of Simalungun community in processing paddy into rice.

Hands as a part of the body that is often used every day in the paddy pounding activity of Simalungun community, is also clearly seen in Manduda dance. The forms of business undertaken in Manduda dance are free and indirect are indicative of the life of the community 
as farmers. Thus, it can be said that Manduda dance is a dance that expresses the pattern of community activities that are frequent and dominant every day.

The style can be expressed in a subtle and meaningful way when performed by dancers who truly know, appreciate and familiarize the movements that are relevant to the movements that exist in the pattern of these activities, which underlie these dance movements.

\section{References}

Lomax, Alan. (1978). Folk Song Style and Culture. New Jersey: Transaction Broks New Brunswick.

Royce, A. (1977). The Anthropology of Dance. London: Indiana University.

Runes, DD, and Scrickel HG. (1946). Encyclopedia of the Art. New York: Philosophical Library.

Sedyawati, Edi. (1981). Tari: Tinjauan Seni Pertunjukan, Jakarta: Dunia Pustaka Jaya. , et al. (1986). "Tari Sebagai Salah Satu Pernyataan Budaya" dalam Fx Sutopo Cokrohamijoyo, et.al. (ed). Pengetahuan Elementer Tari dan Beberapa Masalah Tari. Jakarta: Direktorat Kesenian Departemen Pendidikan dan Kebudayaan.

-----------, et.al. (1991). "Tari Sebagai Media Budaya: Suatu Penilaian Perkembangan di Minangkabau." Laporan Penelitian. Jakarta: Direktorat Sejarah dan Nilai Tradisional Ditjen Kebudayaan Departemen P\&K. 